\title{
Characterization of Temperature-sensitive (ts) Mutants of Coronavirus Infectious Bronchitis Virus (IBV)
}

SHUO SHEN AND DING XIANG LIU

Institute of Molecular Agrobiology, I Research Linke, National University of Singapore, Singapore 117604

\section{INTRODUCTION}

Coronavirus infectious bronchitis virus is a positive-stranded RNA virus, which synthesises a 3'-coterminal nested set of six subgenomic RNAs. Subgenomic RNA transcription and genome replication are directed by the viral replicase, which is expressed in the form of polyproteins $1 \mathrm{a}$ and $1 \mathrm{a} / \mathrm{b}$ and subsequently processed into smaller nonstructural proteins by the virusencoded proteinases. Major structural proteins S (spike protein), E (envelope protein), $\mathrm{M}$ (membrane protein) and $\mathrm{N}$ (nucleoprotein) are translated from subgenomic RNAs 2, 3, 4 and 6 and involved in nucleocapsid and virion assembling (Lai \& Cavanagh 1998). Previous studies demonstrated that mutations and deletions on the structural proteins conferred the coronavirus mouse hepatitis virus ts phenotypes (Masters et al 1994 \& Luytjes et al 1997). However, little is known about the mechanisms involved. In this study, ts mutants were generated by growing wild type virus at progressively lower temperatures from $35^{\circ} \mathrm{C}$ to $28^{\circ} \mathrm{C}$ on Vero cells. Two ts mutants were isolated from passages grown at $29^{\circ} \mathrm{C}$ (ts291602) and $28^{\circ} \mathrm{C}$ (ts282902). Sequence analysis reveals that mutations emerged in the $\mathrm{S}$ protein and an insertion occurred in the $\mathrm{N}$ protein. Biological and biochemical properties of ts mutants were characterised. 


\section{MATERIALS AND METHODS}

\subsection{Virus and cells}

An IBV strain, Beaudette, was first adapted to grow on Vero cells at $37^{\circ} \mathrm{C}$ in our laboratory. In this study, the virus was plaque-purified and then passaged on Vero cells at progressively lower temperatures from $35^{\circ} \mathrm{C}$ to $28^{\circ} \mathrm{C}$. Cells were maintained in complete DMEM medium (GIBCO BRL) supplemented with $10 \%$ newborn calf serum and infected with viruses at low multiplicity of infection (0.1). Plaque assays were performed as described previously (Shen et al 1994).

\section{$2.2 \quad$ RT-PCR and sequencing}

Viral RNA was extracted from partially purified viruses using the RNeasy Mini Kit (Qiagen) according to the manufacturer's instructions. Reverse transcription and polymerase chain reaction (RT-PCR) were performed using the Expand Reverse Transcription and High Fidelity PCR Kits (Boehringer Mannheim). Annealing and extension times of PCR were optimised for amplification of PCR products with different sizes using different primers. More than 100 specific primers were used for amplification, sequencing and cloning. Automated sequencing was carried out using PCR products and specific primers as previously described (Shen $\&$ Liu 2000). Sequence analyses were carried out using the GCG suite of programs.

\subsection{Northern blot}

Plasmid pGEMN1, covering nucleotides 26539 to 27608 under control of the SP6 promoter at the 3'-end of the IBV genome, was linearised with restriction enzyme PvuII (at position 27034). Transcription was performed using Dig Labelling Kit (Boehringer Mannheim) and the linearised template. The transcripts were treated with $20 \mathrm{U} / \mathrm{ml}$ of RNase-free DNase (Boehringer) for $15 \mathrm{~min}$ at $37^{\circ} \mathrm{C}$, extracted with phenol/chloroform and precipitated with equal volume of $4 \mathrm{M}$ ammonium acetate and 6 volumes of ethanol. The pellet was washed once with cold $70 \%$ ethanol, resuspended in $50 \mu \mathrm{l}$ of $\mathrm{H}_{2} \mathrm{O}$ and stored at $-20^{\circ} \mathrm{C}$. Northern blot was performed as described previously (Shen et al 1999). 


\subsection{Analysis of viral structural proteins}

Viral structural proteins were labelled, immunoprecipitated and separated on polyacrylamide gels as described previously (Liu et al 1998).

\section{RESULTS}

\subsection{Isolation of ts mutants of IBV}

An IBV strain Beaudette, grown on Vero cells at $37^{\circ} \mathrm{C}$, was plaquepurified and adapted to progressively lower temperatures by growing at $35^{\circ} \mathrm{C}, 34^{\circ} \mathrm{C}, 33^{\circ} \mathrm{C}, 32^{\circ} \mathrm{C}, 30^{\circ} \mathrm{C}, 29^{\circ} \mathrm{C}$ and $28^{\circ} \mathrm{C}$ for $4,5,7,44,12,21$ and 29 times, respectively. Plaque assays of virus stocks were performed at both $32^{\circ} \mathrm{C}$ and $40^{\circ} \mathrm{C}$. As shown in Table 1 , viruses from early passages could form plaques at both temperatures at almost the same levels, but those from late passages only produced plaques at $32^{\circ} \mathrm{C}$. The results suggested that ts mutants emerged in the cold-adaptation process and dominated quickly when temperature was shifted to $28^{\circ} \mathrm{C}$. Two ts mutant clones, designated ts 291602 and ts 282902 , were plaque-purified from passage $16\left(29^{\circ} \mathrm{C}\right)$, and passage 29 $\left(28^{\circ} \mathrm{C}\right)$, respectively. Plaque assays showed that ts 291602 produced at least 1,000 time less plaques at nonpermissive temperature $\left(40^{\circ} \mathrm{C}\right)$ than at permissive temperature $\left(32^{\circ} \mathrm{C}\right)$, while ts 282902 formed plaques only at permissive temperature. We believed that partially lethal and lethal ts mutants were generated through cold adaptation of the wild type on Vero cells.

\subsection{Analysis of subgenomic RNA synthesis}

Vero cells were infected with viruses at different temperatures. Viral subgenomic RNAs were extracted and detected with a probe complementary to the 3'-end of the positive-sense viral RNA from nucleotides 27034 to 27608 (nucleotide and amino acid numbering refer to those described by Boursnell et al, 1987). As shown in Figure 1, synthesis of viral subgenomic RNAs of ts mutant $28 \mathrm{P} 29$ (passage 29 at $28^{\circ} \mathrm{C}$ ) was hardly detectable under these conditions at $40^{\circ} \mathrm{C}$. On the other hand, normal amounts of the subgenomic RNAs were detected when the ts mutant $28 \mathrm{P} 29$ was grown at $32^{\circ} \mathrm{C}$ and the wild type was grown at both $37^{\circ} \mathrm{C}$ and $40^{\circ} \mathrm{C}$. 
Table 1. Plaque assays of passages grown at different temperatures. Selected passages were assayed at both $32^{\circ} \mathrm{C}$ and $40^{\circ} \mathrm{C}$.

\begin{tabular}{lllll}
\hline Temperature & Passages & Passages assayed & \multicolumn{2}{c}{ Titre $^{\#}$} \\
& & & $32^{\circ} \mathrm{C}$ & $40^{0} \mathrm{C}$ \\
\hline $37^{0} \mathrm{C}$ & Wild type & wt63 & $5.0 \times 10^{1}$ & $2.0 \times 10^{6}$ \\
$32^{\circ} \mathrm{C}$ & $\mathrm{P} 1$ to P44 & $\mathrm{P} 44$ & $2.7 \times 10^{5}$ & $2.0 \times 10^{6}$ \\
$30^{\circ} \mathrm{C}$ & $\mathrm{P} 1$ to $\mathrm{P} 12$ & $\mathrm{P} 12$ & $1.1 \times 10^{5}$ & $1.4 \times 10^{5}$ \\
$29^{\circ} \mathrm{C}$ & $\mathrm{P} 1$ to P21 & $\mathrm{P} 10$ & $1.5 \times 10^{4}$ & $5.0 \times 10^{3}$ \\
& & $\mathrm{P} 13$ & $2.5 \times 10^{5}$ & $2.5 \times 10^{2}$ \\
& & $\mathrm{P} 21$ & $5.0 \times 10^{5}$ & $1.3 \times 10^{3}$ \\
$28^{0} \mathrm{C}$ & $\mathrm{P} 1$ to P29 & $\mathrm{P} 1$ & $1.0 \times 10^{5}$ & $5.0 \times 10^{1}$ \\
& & $\mathrm{P} 5$ & $3.3 \times 10^{6}$ & $\mathrm{NP}$ \\
& & $\mathrm{P} 29$ & $2.9 \times 10^{6}$ & $\mathrm{NP}$ \\
\hline
\end{tabular}

\# indicated as $\mathrm{PFU} / \mathrm{ml} ;{ }^{*}$ no plaques formed.

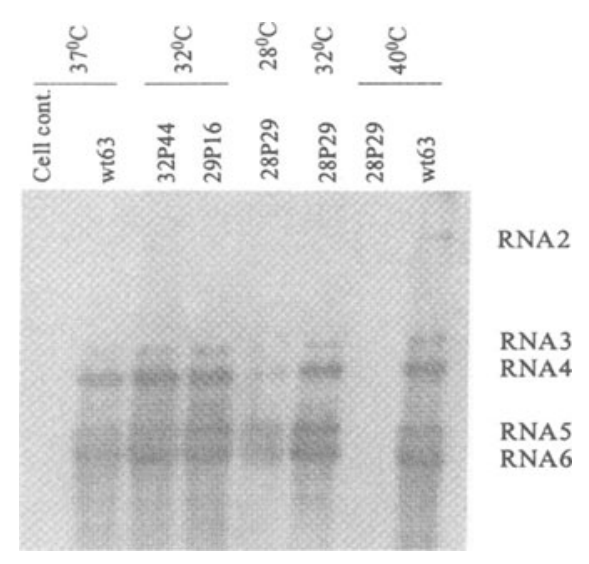

Figure 1. Subgenomic RNA synthesis. Northern blot analysis was carried out to detect viral subgenomic RNA synthesis of ts mutant $28 \mathrm{P} 29$ (passage 29 at $28^{\circ} \mathrm{C}$ ) at $28^{\circ} \mathrm{C}, 32^{\circ} \mathrm{C}$ and $40^{\circ} \mathrm{C}$ (as indicated at the top). Cultures infected wild type wt63, passages 32P44 (passage 44 at $32^{\circ} \mathrm{C}$ ) and $29 \mathrm{P} 16$ (passage 16 at $29^{\circ} \mathrm{C}$ ) were used as controls and mock-infected culture as negative control. Subgenomic RNAs 2 to 6 are indicated.

\subsection{Analysis of viral structural proteins}

Cells were infected with wild type virus and ts mutants and viral proteins were labelled with ${ }^{35} \mathrm{~S}$-methionine. Viral structural proteins were immunoprecipitated with anti-IBV and antisera against the $\mathrm{M}$ and $\mathrm{N}$ proteins (Fig 2). The results revealed that the $\mathrm{N}$ proteins of the two mutants migrated slightly more slowly than that of the wild type, indicating mutation or insertion in the $\mathrm{N}$ protein of the ts mutants. 


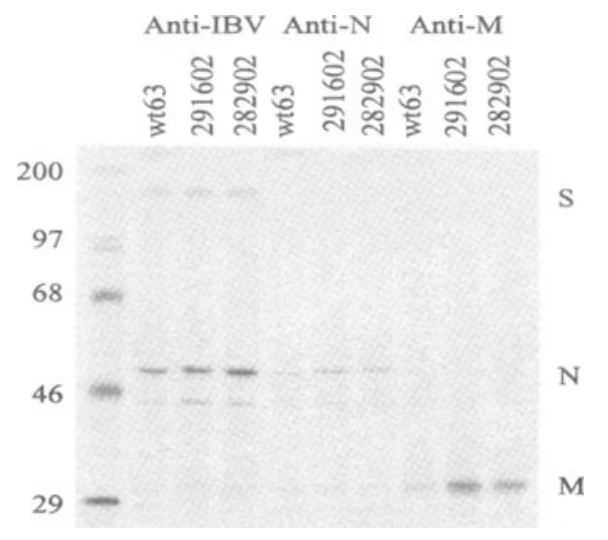

Figure 2. Structural protein profiles of plaque-purified wild type wt63, ts mutants ts 291602 and ts282902. Labeled viral proteins were immuno-precipitated with antisera as indicated and separated on a $12.5 \%$ SDS polyacrylamide gel. Spike (S), nucleocapsid $(\mathrm{N})$ and membrane (M) proteins are indicated. Numbers indicate molecular masses in kilodaltons.

\subsection{Sequence analysis of the wild type virus and ts mutants}

Nucleotide sequences of the wild type virus and ts mutants were determined using RT-PCR products of the three viruses. An insertion of 9 nucleotides, located near the 5'-end of the $\mathrm{N}$ gene of both mutants, was identified. This resulted in an in-frame Arg-Thr-Leu insertion in the $\mathrm{N}$ protein between the tenth and the eleventh residues of the wild type (Table 2 ). The insertion corresponds to the slow migration of the $\mathrm{N}$ protein of the ts mutants. In addition, three point mutations (Table 2), which caused two amino acid substitutions (a Gln ${ }^{294}$ to $\mathrm{Leu}^{294}$ and an $\mathrm{Ile}^{769}$ to $\mathrm{Met}^{769}$ ) in the S protein of both mutants, were identified. To date, sequences of the 5'- and 3 '-NCR, half of the 1 a region, whole $1 \mathrm{~b}$ and structural regions of the wild type and ts mutant have been determined and no other mutations, insertions and deletions of the deduced gene products were identified except those mentioned above.

Table 2. Sequence analysis of the plaque-purified wild type and ts mutants.

\begin{tabular}{lllllll}
\hline \multirow{2}{*}{$\begin{array}{l}\text { Nucleotide } \\
\text { position }\end{array}$} & \multicolumn{2}{c}{$\mathrm{Wt63}$} & \multicolumn{2}{c}{ ts291602 } & \multicolumn{3}{c}{ ts282902 } \\
\cline { 2 - 7 } & $\mathrm{Nt}^{\#}$ & $\mathrm{Aa}^{*}$ & $\mathrm{Nt}$ & $\mathrm{Aa}$ & $\mathrm{Nt}$ & $\mathrm{Aa}$ \\
\hline $21247 / 8$ & $\mathrm{CA}$ & $\mathrm{Q}$ & $\mathrm{UU}$ & $\mathrm{L}$ & $\mathrm{UU}$ & $\mathrm{L}$ \\
22674 & $\mathrm{~A}$ & $\mathrm{I}$ & $\mathrm{G}$ & $\mathrm{M}$ & $\mathrm{G}$ & $\mathrm{M}$ \\
$25902 / 3$ & - & - & AGGACCUUA & RTL & AGGACCUUA & RTL \\
\hline
\end{tabular}

\# nucleotide; * amino acid; - locus corresponding to the insertion in the mutants. 


\section{CONCLSION}

In this study, ts mutants emerged in the process of passaging the wild type IBV at progressively low temperatures. Under this selective pressure, ts mutants dominated soon in the viral population when the temperature shifted from $29^{\circ} \mathrm{C}$ to $28^{\circ} \mathrm{C}$. To date, $80 \%$ of the genomes of the mutants have been sequenced and two mutations, $\mathrm{Glu}^{294}$ to $\mathrm{Leu}^{294}$ and $\mathrm{Ile}^{769}$ to $\mathrm{Met}^{769}$, in the S protein and an Arg-Thr-Leu insertion in the $\mathrm{N}$ protein of the ts mutants have been identified. The insertion of the mutants was confirmed by PAGE analysis. It is noted that synthesis of the viral subgenomic RNAs of the ts mutants was hampered at the nonpermissive temperature, although no mutations were identified in the $1 \mathrm{~b}$ polyprotein including the polymerase domains. Further studies are underway to map the defective gene(s) in structural and/or nonstructural regions for ts phenotypes and to understand the mechanisms involved.

\section{REFERENCES}

Boursnell, M.E., Brown, T.D., Foulds, I.J., Green, P.F., Tomley, F.M., \& Binns, M.M. 1987, Completion of the sequence of the genome of the coronavirus avian infectious bronchitis virus. J. Gen. Virol. 68 (Pt 1): 57-77.

Lai, M..M.C., \& Cavanagh, D., 1998, The Molecular Biology of Coronaviruses. In Advances in Virus Research 48: 1-99.

Liu, D.X., Shen, S., Xu, H.Y., \& Wang, S.F., 1998, Proteolytic mapping of the coronavirus infectious virus $1 \mathrm{~b}$ polyprotein: evidence for the presence of four cleavage sites of the 3Clike proteinase and identification of two novel cleavage products. Virology 246: 288-297.

Luytjes, W., Gerritsma, H., Bos, E., \& Spaan, W., 1997, Characterization of two temperaturesensitive mutants of coronavirus mouse hepatitis virus strain A59 with maturation defects in the spike protein. J. Virol. 71(2): 949-955.

Masters, P.S., Koetzner, C.A., Kerr, C.A., \& Heo, Y., 1994, Optimization of targeted RNA recombination and mapping of a novel nucleocapsid gene mutation in the coronavirus mouse hepatitis virus. J. Virol. 68:328-337.

Shen, S., Burke, B., \& Desselberger, U., 1994, Rearrangement of the VP6 gene of a group A rotavirus in combination with a point mutation affecting trimer stability. J.Virol. 68:16821688.

Shen, S., McKee, T.A., Wang, Z.D., Desselberger, U., \& Liu, D.X., 1999, Sequence analysis and in vitro expression of genes 6 and 11 of an ovine group B rotavirus isolate, KB63: evidence for a non-defective, C-terminally truncated NSP1 and a phosphorylated NSP5. J. Gen. Viral. 80:2077-2085.

Shen, S., \& Liu, D.X., 2000, Determination of the complete nucleotide sequence of a vaccine strain of porcine reproductive and respiratory syndrome virus and identification of the NSP2 gene with an unique insertion. Arch. Virol. 145:871-883. 